\title{
The Influence of Watershed Morphometry to River Discharge Variation (Case Study of Bengkulu Watershed, Indonesia)
}

\author{
Gita Ivana Suci Lestari Faski ${ }^{1,2}$ and Ignasius Loyola Setyawan Purnama ${ }^{1}$ \\ ${ }^{1}$ Faculty of Geography, Universitas Gadjah Mada, Yogyakarta, Indonesia \\ ${ }^{2}$ Indonesian Agency for Meteorology, Climatology and Geophysics, Bengkulu Climatology Station, Indonesia \\ e-mail : gita.ugm2019@gmail.com
}

\begin{abstract}
Morphometric analysis in a watershed is a requirement in analyzing hydrological conditions in a watershed, because the properties of river networks and their relationship to each other will affect the condition of water resources in the watershed. This study aims to analyze the variations in the discharge of two rivers in the upper Bengkulu watershed and the morphometric aspects that influence it. For this reason, several morphometric aspects are calculated, such as the area of the watershed, circulation ratio, median elevation and slope. The results showed that the Rindu Hati River had a higher monthly discharge than the Susup River. The sizeable difference in discharge between the Rindu Hati and Susup Rivers is due more to differences in the size of the area. As is known, the total area of the Rindu Hati Sub-watershed is $184.2 \mathrm{~km}^{2}$, while the Susup Sub-watershed is $103.6 \mathrm{~km}^{2}$. With a large area, the Rindu Hati Subwatershed will be able to accommodate a large amount of rainwater as well.
\end{abstract}

\section{Introduction}

A watershed is a unitary area of an ecosystem that is bounded by a topographical water separator and functions as a collector, storage and channel for water, nutrient sediments in the river system, all of which come out through one outlet [1-4]. This definition implies that a watershed is a landscape area with a topographical boundary in the form of a line connecting the highest points in the area. In addition, referring to this definition implies that in addition to being a hydrological unit, watershed is also a unitary ecosystem area. As an ecosystem unit, in the watershed there will also be dynamic interactions between elements of living things, the biophysical environment and chemical elements. Likewise, there is a balance phenomenon between the input and output of matter and energy [5-6].

In natural resource management efforts, watershed is often used as a unit of analysis because of the three components of the ecosystem, namely abiotic (soil, water), biotic (vegetation) and culture (humans and their social relationships), water is the most obvious aspect of its movement (following the hydrological cycle). and its territory. However, problems arise related to the increase in watershed damage during the $21^{\text {st }}$ century [7-8]. According to [9], the impact assessment of various land management will help in identifying watershed management efforts, whereas according to [10], data related to soil loss and sedimentation are very useful for identifying the location of soil erosion in conservation efforts. In the end, integrated watershed management is needed that requires holistic thinking and involves the participation of stakeholders [11-14]
As previously mentioned, morphometric analysis in a watershed is a requirement in assessing hydrology, because the behavior of river networks and their relationship with each other affects the water resources in the watershed [15-16]. Watershed morphometry, which includes the area, shape and density of river flows, affects the infiltration system, water storage and surface runoff, including sediment transported in the runoff [17]. Watershed with a large area will tend to have a greater amount of rainfall, so that the amount of flow that is discharged from the watershed is also greater. A watershed that has a round shape will tend to have a higher flood discharge, because the rainfall that falls into the watershed will quickly reach the outlet. Likewise, watersheds that have many river branches will have a higher peak discharge because water will enter the river more quickly and easily [18].

The Bengkulu Watershed is located in two regency, namely Central Bengkulu Regency and Bengkulu City. which consists of several districts, namely Taba Penanjung, Karang Tinggi, Pondok Kelapa and Talang Empat Districts in Central Bengkulu Regency, as well as Gading Cempaka, Muara Bangka Hulu, and Segara Bay Districts in Bengkulu City. The Bengkulu watershed is divided into 3 sub-watersheds, namely the Rindu Hati sub-watershed and the Susup subwatershed in the upstream part and the Bengkulu Hilir sub-watershed at the downstream part. The upstream part of the watershed is in the Bukit Barisan mountains and drainage into the Indian Ocean. With the relatively short distance between the upstream and downstream and the narrow river width, the Bengkulu Watershed has a relatively steep to very steep slope with high river flow velocity [19]. 
With the physical characteristics of the watershed, as well as the damage in the upstream part due to coal mining activities and changes in land use from protected forests to production forests, the time of concentration of river flow in the watershed is getting smaller. As a result, the runoff coefficient increases causing an increase in river discharge which can cause flooding [20]. Therefore, the management of water resources in the Bengkulu watershed is very important because of these problems. Watershed morphometric analysis forms the basis for watershed management policies.

\section{Methodology}

The area of the watershed is determined based on its watershed boundaries, which are delineated on the topographic map. Furthermore, the actual watershed area is determined by multiplying the area of the watershed in the topographic map with the map scale. As is known, the wider the watershed area, the greater the river discharge, because the rainfall captured in the watershed will also be greater.

The shape of the watershed can be represented through a circulation ratio (Rc) value which is determined by the following equation:

$$
\mathrm{Rc}=\frac{\mathrm{A}}{\mathrm{Ac}}
$$

where $\mathrm{Rc}$ is the circulation ratio, $\mathrm{A}$ is the area of the watershed, Ac is the area of a circle with a circumference equal to the circumference of the watershed.

Median elevation is the point of elevation of the watershed which will divide the watershed area by an equal area. The method of determination is done by making a hypsometric curve, namely the curve of the relationship between the height and the watershed area above that height. The median elevation was determined to be $50 \%$ or $1 / 2$ the area of the watershed. In a watershed study, the median elevation needs to be known, among other things, to determine the average temperature in the watershed. In addition, the median elevation is also often used as a parameter that refers to the height of the watershed.

The slope of the watershed is determined by analyzing the contour lines. The area with the total length of the large contour lines will have a steeper slope of the watershed than the area with the shorter total length of the contour lines.

\section{Results and discussion}

\subsection{Watershed morphometry}

The Bengkulu Watershed has an area of $500.5 \mathrm{~km}^{2}$, which is divided into the Rindu Hati Sub-watershed covering an area of $184.2 \mathrm{~km}^{2}$, the Susup Subwatershed covering an area of $103.6 \mathrm{~km}^{2}$ and the Bengkulu Hilir Sub-watershed covering an area of $212.7 \mathrm{~km}^{2}$. Because the wider the area, the greater the river discharge, the Bengkulu Hilir River will likely have the largest discharge.
The shape of the watershed can be identified from a circulation ratio $(\mathrm{Rc})$ value. A Rc value greater than 0.5 indicates that the area has high relief and a permeable surface, so that the water flow lag time is longer, while a low Rc value indicates low relief and a watertight surface, resulting in a faster water flow lag time (Mokarram and Sathyamoorthy, 2015).

According to Vienastra (2018), if the Rc value gets closer to 1 , the watershed will tend to be round, but if the Rc value approaches 0 , the watershed will be elongated. A round watershed will have a high runoff discharge because it will drain water faster to the outlet, while an elongated watershed will take longer to drain water to the outlet. Rindu Hati and Susup Subwatersheds have Rc values of 0.59 and 0.55 , so they tend to be round in shape, while Bengkulu Hilir Subwatersheds have Rc 0.35 so that they are elongated.

Drainage density (Dd) is a measure that shows the length of the river in the watershed area per one square kilometer. Therefore, the greater the drainage density value, the better the drainage system in the area. According to Linsley (1959), if the drainage density value is less than 1 , it indicates that the drainage system in the watershed is not good and there is inundation. If the drainage density value is between 1 and 5, it indicates a good drainage system and no inundation. If the drainage density value is more than 5 , it indicates that the drainage system is not good and there is drought.

The value of drainage density in Rindu Hati Subwatershed is $0.004 \mathrm{~m} / \mathrm{m}^{2}$, Susup Sub-watershed 0.006 $\mathrm{m} / \mathrm{m}^{2}$ and Bengkulu Hilir Sub-watershed $0.005 \mathrm{~m} / \mathrm{m}^{2}$, so that the flow density in all sub-watersheds is included in the low flow density category. According to Antoko and Sukmana (2007), watersheds with a drainage density value $<0.25 \mathrm{~m} / \mathrm{m}^{2}$ have a low capacity to store water and have the potential to experience inundation in the downstream side of the river. As a result, the runoff volume will be high and the discharge will increase.

The Bengkulu Watershed has an elevation of 01,025 m above sea level. Rindu Hati Sub-watershed has a height between 16-1,025 m, Susup Subwatershed 17-975 $\mathrm{m}$ and Bengkulu Hilir Subwatershed 0-427 m. Judging from its median elevation, Rindu Hati Sub-watershed has a median elevation of $257 \mathrm{~m}$, Susup Sub-watershed $155 \mathrm{~m}$ and Bengkulu Hilir Sub-watershed $41 \mathrm{~m}$. The altitude of the place will affect the amount of rainfall due to orographic effects, so based on the altitude of the location, the Rindu Hati Sub-watershed and Susup Sub-watershed will have a greater amount of rain and a larger runoff volume.

Judging from its slope, most of the Rindu Hati Subwatershed has an $8-40 \%$ slope or is in the form of a wavy, hilly and steep area, likewise most of the Susup Sub-watershed also has an $8-40 \%$ slope. However, Bengkulu Hilir Sub-watershed has a slope of $0-15 \%$ or is gentle and hilly, so that the water flow in the Bengkulu Hilir River tends to be slower and the water infiltration into the ground is more. 


\subsection{River discharge}

In general, the Rindu Hati River has a higher monthly discharge than the other two rivers. In the 2009-2013 period, the average discharge of the Rindu Hati River was $163.48 \mathrm{~m}^{3} / \mathrm{second}$, then decreased to 161.29 $\mathrm{m}^{3} /$ second in the 2014-2018 period. The Susup River has a discharge of $91.69 \mathrm{~m}^{3} / \mathrm{second}$ in the 2009-2013 period and decreased to $90.24 \mathrm{~m}^{3} /$ second in the 2014 2018 period. However, for the Bengkulu Hilir River, there was an increase in discharge, which amounted to
$131.89 \mathrm{~m}^{3} /$ second in the $2009-2013$ period to 149.49 $\mathrm{m}^{3} / \mathrm{second}$ in the 2014-2019 period. This increase in river discharge is likely due to changes in land use.

It can be said that by considering the pattern (Figure 1), the variations in the monthly discharge of the Rindu Hati and Susup Rivers in 2009-2018 are similar, while the Bengkulu Hilir River has a slightly different pattern of discharge variations.

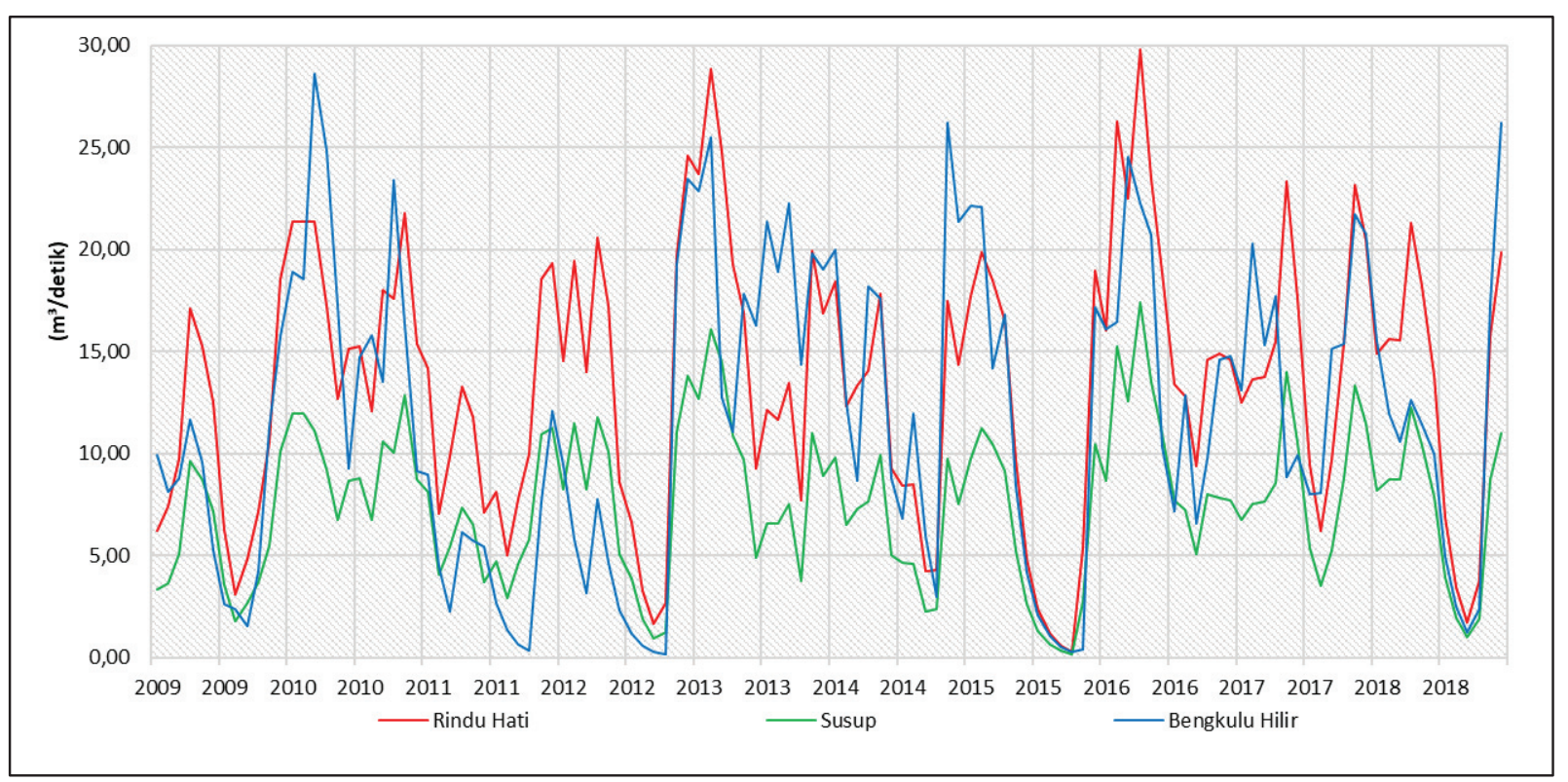

Fig. 1. Variations of river discharge in the Bengkulu Watershed 2009-2018 [21].

\subsection{Watershed morphometry and river discharge}

Beside watershed morphometry, other aspects that can affect river discharge are land use and rainfall volume. The dominant land use in Rindu Hati and Susup Subwatersheds is relatively the same, namely dry land and bush farming, while in Bengkulu Hilir Sub-watershed, apart from dry land and bush farming, it also includes settlements, rice fields and open land. (Figure 2).
For annual rainfall, Rindu Hati and Susup subwatersheds also have almost the same amount, namely $3,703 \mathrm{~mm}$ and $3,790 \mathrm{~mm}$, while the amount of rainfall in Bengkulu Hilir sub-watershed is lower, namely 3340 $\mathrm{mm}$. Based on the similarity of the data for these two aspects, the analysis of the Rindu Hati and Susup River discharge can be carried out only based on their morphometrics (Table 1).

Table 1. The relationship between watershed morphometry and river discharge.

\begin{tabular}{|l|c|c|c|c|c|c|}
\hline \multirow{2}{*}{ Sub-Watershed } & \multicolumn{5}{|c|}{ Watershed Morphometry } & \multirow{2}{*}{$\begin{array}{c}\text { River Discharge } \\
\left(\mathrm{m}^{3} / \text { second }\right)\end{array}$} \\
\cline { 2 - 7 } & $\begin{array}{c}\text { Area } \\
\left(\mathrm{km}^{2}\right)\end{array}$ & $\begin{array}{c}\text { Circulation } \\
\text { Ratio }\end{array}$ & $\begin{array}{c}\text { Drainage Density } \\
\left(\mathrm{m} / \mathrm{m}^{2}\right)\end{array}$ & $\begin{array}{c}\text { Median } \\
\text { Elevation }(\mathrm{m})\end{array}$ & Slope (\%) & 162.38 \\
\hline Rindu Hati & 184.2 & 0.59 & 0.004 & 257 & $8-40$ & 90.96 \\
\hline Susup & 103,6 & 0.55 & 0.006 & 155 & $8-40$ & 140.69 \\
\hline Bengkulu Hilir & 212,7 & 0.35 & 0.005 & 41 & $0-15$ & \\
\hline
\end{tabular}

Source : [21] 


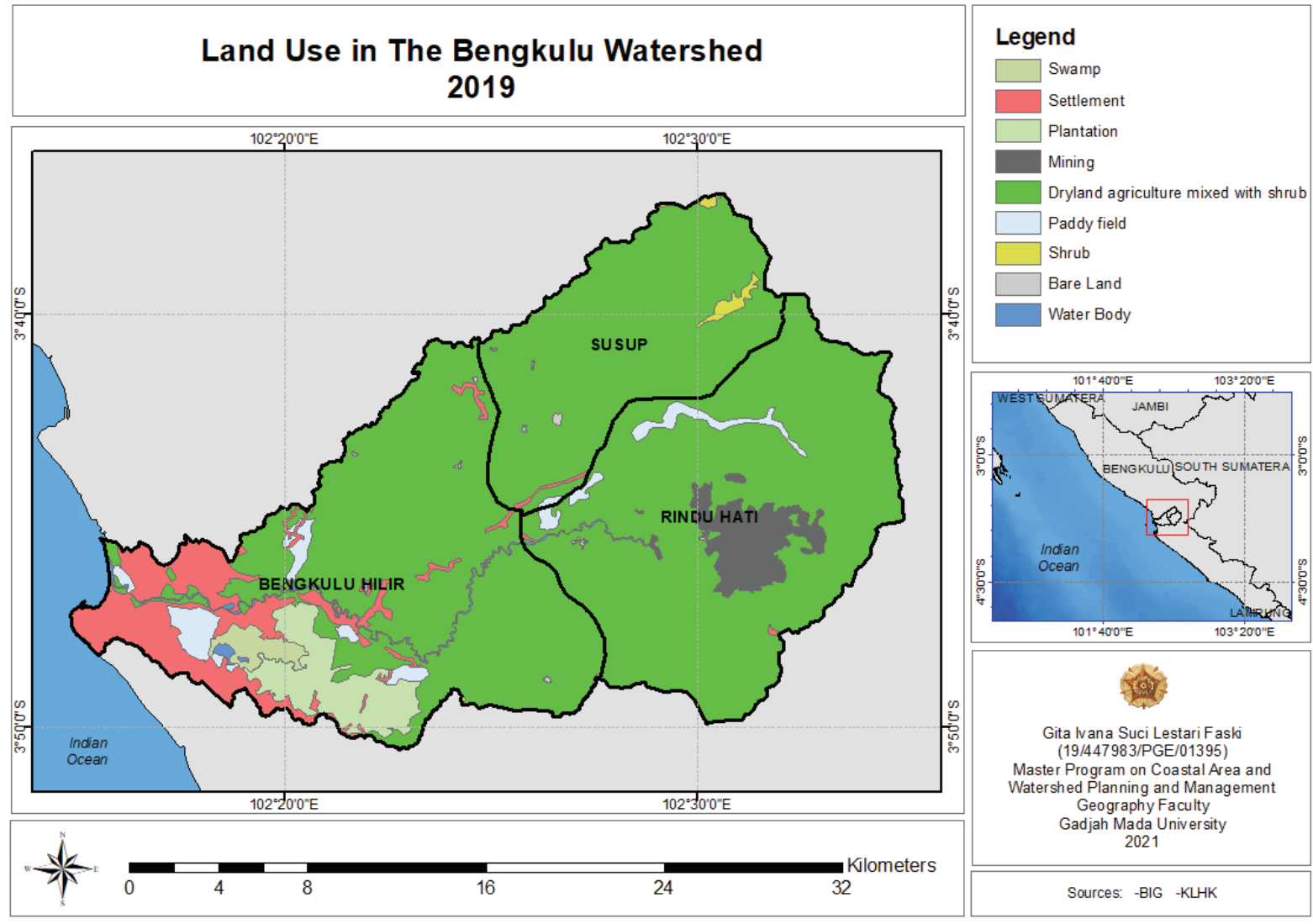

Fig. 2. Land use in the Bengkulu Watershed [21].

Looking at Table 1, it can be seen that the Rindu Hati River has an average monthly river discharge that is much higher than that of the Susup River. The Rindu Hati River has a monthly discharge of 162.38 $\mathrm{m}^{3} /$ second, while the Susup River has a monthly discharge of $90.96 \mathrm{~m}^{3} /$ second. The slope of the two sub-watersheds is the same, namely between $8-40 \%$, so that the slope aspect can be neglected. The circulation ratio values of the two sub-watersheds are also almost the same, namely 0.59 and 0.55 , so they tend to be round in shape and will have high discharge because they will flow water more quickly to the outlet. Because the values are similar, the circulation ratio aspect can also be ignored.

The drainage density value in the Rindu Hati Subwatershed is $0.004 \mathrm{~m} / \mathrm{m}^{2}$, while the Susup Subwatershed is $0.006 \mathrm{~m} / \mathrm{m}^{2}$, so that the drainage density of the two sub-watersheds is also in the same drainage density category, which is low, so it has the ability to store water which is low and has the potential experiencing inundation in the downstream side of the river.

Regarding the median elevation aspect, Rindu Hati Sub-watershed has a median elevation of $257 \mathrm{~m}$ and Susup Sub-watershed of $155 \mathrm{~m}$. Theoretically, altitude can affect the amount of rainfall due to orographic effects, so that the Rindu Hati Sub-watershed should have more rain than the Susup Sub-watershed. In fact, Susup Sub-watershed has a higher amount of rain than
Rindu Hati sub-watershed although the difference is not much, namely $3,703 \mathrm{~mm}$ and $3,790 \mathrm{~mm}$. This is probably due to the influence of the differences in the area of the two sub-watersheds, where the Rindu Hati Sub-watershed has a larger area than the Susup Subwatershed.

Based on the description of the four morphometric aspects, it can be seen that the sizeable difference in discharge between the Rindu Hati River and the Susup River is more due to differences in area size. As is known, the total area of the Rindu Hati Sub-watershed is $184.2 \mathrm{~km}^{2}$, while the Susup Sub-watershed is 103.6 $\mathrm{km}^{2}$. With a large area, the Rindu Hati Sub-watershed will be able to accommodate a large amount of rainwater as well.

\section{Conclusion}

1) Rindu Hati River has a higher average monthly discharge than Susup River.

2) The sizeable difference in discharge between the Rindu Hati and Susup Rivers is more due to differences in the size of the area. As is known, the total area of the Rindu Hati Sub-watershed is 184.2 $\mathrm{km}^{2}$, while the Susup Sub-watershed is $103.6 \mathrm{~km}^{2}$. With a large area, the Rindu Hati Sub-watershed will be able to accommodate a large amount of rainwater as well. 


\section{Acknowledgement}

This paper is part of a study entitled " Water Balance Analysis of Bengkulu Watershed in Relation to the Watershed Physical Characteristics", financed by Final Assignment Recognition (Rekognisi Tugas Akhir/RTA) Programme Universitas Gadjah Mada year 2021 .

\section{References}

1. Wannielista, M., R. Kersten and R. Eaglen. John Wiley and Sons Inc., New York (1997)

2. Davie T. Routledge, Taylor \& Francis Group, London (2008)

3. Purnama I L S. Jurnal Rekayasa Lingkungan 6 (3) : 291-301 (2010)

4. Suprayogi, S., Purnama, I. L. S., \& Darmanto, D. 2014. Gadjah Mada University Press (2014)

5. Griend, A.A.V. Institute of Earth Sciences Free University, Amsterdam (1979)

6. Asdak, C. Gadjah Mada University Press, Yogyakarta (2005)

7. Lee. R. Gadjah Mada University Press, Yogyakarta (1990)

8. Romulo C L., Posner S.,Cousins S., Fair J H., Bennett D E., Stearns H H., Richards R C., McDonald R I. Nature Communication (2018) 9:4375 (2018)

9. Gashaw T., Worqlul A.W., Dile Y., Addisu S., Bantider A., Zeleke. G. 2020. Heliyon 6 (2020) e04777 (2020)
10. Aneseyee A B., Elias E., Soromessa T., Feyisa G L. Science of the Total Environment 728 (2020) 138776 (2020)

11. Holen, B.V. Environment and Urbanization 13 : 209-222. (2001)

12. Athari Z., Rad G P., Abbasi E., Alibaygia A., Westholm E. Water Policy 19 (2017)1143-1159 (2017)

13. Purnama I L S. Proceeding of International Seminar : Utization of Geospatial Information to Raise Environmental Awareness in Realizing The Nation Character (2012)

14. Purnama I L S. IOP Conference Series: Earth and Environmental Science 451 (2020) 012085 (2020)

15. Rai, P. K., Mohan, K., Mishra, S., Ahmad, A., \& Mishra, V. N. Applied Water Science 7 : 217-232 (2017)

16. Purnama I L S., Trijuni S., Hanafi F., Aulia T., Razali R. Magister Perencanaan dan Pengelolaan Pesisir dan DAS Fakultas Geografi UGM, Yogyakarta (2012)

17. Antoko, B. S., \& Sukmana, A. Jurnal Penelitian Hutan Dan Konservasi Alam 4 (5) : 485-497. (2007)

18. Suprayogi, S., Purnama, I. L. S., \& Darmanto, D. 2014. Gadjah Mada University Press (2014)

19. Satmaidi, E., Muthia, A., Wulandari A. Bina Hukum Lingkungan, 2 (2), 198-214. (2018)

20. Karima A. Thesis. Institut Pertanian Bogor (2017).

21. Faski G I S L. Thesis. Magister Perencanaan dan Pengelolaan Pesisir dan DAS Fakultas Geografi Universitas Gadjah Mada (2021) 